\title{
PENINGKATAN KEMAMPUAN BERBICARA BAHASA INGGRIS DENGAN PERMAINAN ULAR NAGA PADA SISWA KELAS VII - J SEMESTER 2 SMPN 3 MRANGGEN TAHUN PELAJARAN 2016 - 2017
}

\author{
Oleh: Prihariyani \\ SMPN 3 Mranggen, Demak \\ Jl.Pucanggading Raya Batursari, Mranggen, Demak \\ Email: disoprihariyani@gmail.com
}

\begin{abstract}
Abstrak
Diruang kelas, sering sering terlihat murid - murid mengalami kesulitan berbicara. Hal ini bisa dilihat dari nilai kemampuan berbicara mereka saat diberi tugas untuk berbicara dalam bahasa Inggris. Mereka diberi banyak model dan tugas yang bervariasi tetapi mereka masih tetap tidak berani berbicara dalam bahasa Inggris dengan benar. Berdasarkan permaslahan diatas penerapkan model Permainan Ular Naga untuk memecahkan masalah dilakukan penelitian Tindakan Kelas dengan menggunakan Permainan Ular Naga sebagai media mengajar untuk berbicara materi teks Deskriptif dengan subyek We Love What We Do. Hasil yang dicapai menunjukkan penggunaan permainan Ular Naga dalam mengajar berbicara dapat meningkatkan kemampuan berbicara Bahasa Inggris kelas class VII-J Semester 2 SMPN 3 Mranggen.The use of Penggunaan permainan Ular Naga dapat memotivasi murid untuk berbicara dengan lebih baik karena dua kepala lebih bagus dari pada satu kepala / pemikiran. Penelitian ini juga menerapkan kerja kelompok karena merekaekerja dalam kelompok.

Hasil dari penelitian ini menunjukkan bahwa permainan Ular Naga dapat meningkatkan nilai berbicara murid dari 67.7 disiklus 1 menjadi 81.1 disiklus 2. Aktifitas belajar siswa juga meningkat dari 77,4\% menjadi $100 \%$ disiklus 2.Hasil penelitian ini menunjukkan bahwa penggunaan permainan Ular Naga dapat meningkatkan hasil berbicara dan aktifitas belajar siswa dalam pengajaran berbicara bahasa Inggris untuk mengajar materi teks deskriptif We Love What We Do.
\end{abstract}

Kata Kunci: Speaking, Descriptive Text, Dragon Snake Play.

\section{Pendahuluan}

Kita perlu mengetahui sejak awal dalam belajar bahasa inggris adalah untuk apa kita belajar bahasa Inggris? Apakah hanya sekedar belajar, atau untuk kebutuhan. Terdapat banyak alasan untuk kita tak hentinya belajar English, terlebih lagi di era globalisasi ini kebutuhan akan bahasa Inggris nyata-nyata sangat penting. Era globalisasi mendorong kita untuk beradaptasi, beradaptasi pada tatanan kehidupan yan berterima umum.

Pentingnya belajar bahasa inggris tidak boleh kita abaikan begitu saja, tanpa bahasa Inggris memang kita masih bisa hidup, namun kehidupan ini telah berkembang pesat dan mengharuskan kita sebagai pihak yang ada dalam lingkaran globalisasi untuk ikut serta dalam tatanan kehidupan yang semakin maju. Pada pembelajaran Bahasa Inggris SMP baik kelas 7, 8, dan 9, pembelajaran berbicara (speaking) merupakan salah satu kompetensi yang harus diajarkan pada siswa. Silabus pembelajaran bahasa Inggris kelas 7 semester genap, mengamanatkan agar siswa mampu: Mengungkapkan makna dan langkah retorika dalam essai pendek sederhana dengan menggunakan ragam bahasa tulis secara akurat, lancar dan berterima.

\subsection{Identifikasi Masalah}

Berdasarkan hasil investigasi ditemukan beberapa masalah yang muncul selama pelaksanaan pembelajaran berlangsung yang perlu diidentifikasi.Adapun permasalahan dari segi peserta didik adalah kurang motivasi belajar,tingkat penguasaan materi masih rendah, kurang tertarik pada pelajaran . Rendahnya nilai berbicara siswa.Sedangkan dari guru cenderung menggunakan metode yang mudah.

\subsection{Perumusan Masalah}


Masalah yang terdapat pada pelajaran teks deskriptif mengenai we love what we do mencakup

a. Bagaimaa meningkatkan kemampuan speaking dalam mengajar bahasa Inggris siswa kelas VII- J Semester 2 dengan Permainan Dragon Snake SMPN 3 Mranggen Tahun Pelajaran 2016 - 2017

b. Apakah penggunaan Permainan Dragon Snake dalam mengajar bahasa Inggris dapat meningkatkan motivasi belajar siswa kelas VII- J Semester 2 SMPN 3 Mranggen Tahun Pelajaran 2016 - 2017 ?

\subsection{Tujuan}

Secara umum tujuan penelitian ini adalah untuk mengetahui peningkatan kemampuan berbicara siwa dalam pelajaran bahasa Inggris.

Tujuan Khususnya

a. Untuk mengetahui peningkatan kemampuan berbicara siswa kelas VII- J Semester 2 SMPN 3 Mranggen Tahun Pelajaran 2016 - 2017.

b. Untuk mengetahui peningkatkan motivasi belajar siswa siswa kelas VII- J Semester 2 dalam bahasa Inggris dengan Permainan Dragon Snake SMPN 3 Mranggen Tahun Pelajaran 2016-2017.

\subsection{Manfaat Penelitian}

Berdasarkan perbaikan pembelajaran yang ditempuh dalam 2 siklus, maka penulis menemukan adanya manfaat perbaikan pembelajaran:

a. Bagi Guru

Penelitian ini bermanfaat untuk memperbaiki pembelajaran yang dikelolanya, karena dengan adanya perbaikan menimbulkan rasa puas karena telah melakukan sesuatu untuk meningkatkan kualitas pembelajarannya.

b. Bagi Siswa

Dengan adanya perbaikan pembelajaran maka dapat meningkatkan hasil belajar peserta didik.

c. Bagi Sekolah

Penelitian itu dapat meningkatkan kualitas pendidikan untuk peserta didik.

\section{Kajian Teori}

\subsection{Kurikulum 2013}

Bahasa Inggris tidak dapat dipungkiri adalah bahasa utama komunikasi antarbangsa dan sangat diperlukan untuk berpartisipasi dalam pergaulan dunia. Makin datarnya dunia dengan perkembangan teknologi informasi dan komunikasi menyebabkan pergaulan tidak dapat lagi dibatasi oleh batas-batas negara.Kurikulum 2013 menyadari peran penting bahasa Inggris tersebut dalam menyampaikan gagasan melebihi batas negara Indonesia serta untuk menyerap gagasan dari luar yang dapat dipergunakan untuk kemaslahatan bangsa dan negara sebagai akibat datarnya dunia.Kurikulum 2013 dirancang untuk menyongsong model pembelajaran Abad 21.

Di dalamnya terdapat pergeseran pembelajaran dari peserta didik diberi tahu menjadi peserta didik mencari tahu dari berbagai sumber belajar melampaui batas guru dan satuan pendidikan.Peran bahasa Inggris dalam model pembelajaran seperti itu menjadi sangat sentral mengingat lebih banyak sumber belajar dalam bahasa Inggris dibanding semua sumber belajar dalam semua bahasa lainnya digabungkan.Sejalan dengan peran di atas, pembelajaran bahasa Inggris untuk SMP/MTs Kelas VIII yang disajikan untuk meningkatkan kemampuan berbahasa.Penyajiannya adalah dengan menggunakan pendekatan pembelajaran berbasis teks, baik lisan maupun tulis, dengan menempatkan bahasa Inggris sebagai sarana berkomunikasi.

Pemahaman terhadap jenis, kaidah dan konteks suatu teks ditekankan sehingga memudahkan peserta didik menangkap makna yang terkandung dalam suatu teks maupun menyajikan gagasan dalam bentuk teks yang sesuai sehingga mudah dipahami orang lain. Mengingat bahasa Inggris baru secara resmi diajarkan mulai Kelas VII SMP/MTs, komunikasi yang disampaikan di sini adalah komunikasi sehari-hari. Bagi beberapa daerah yang telah mengajarkan bahasa Inggris mulai dari kelas-kelas akhir 
SD/ MI, materi yang disampaikan di sini perlu diperkaya dengan materi tambahan yang disesuaikan dengan kemampuan peserta didik.

Dalam Kurikulum 2013 yang menekankan pentingnya keseimbangan kompetensi sikap, pengetahuan, dan keterampilan, kemampuan berbahasa Inggris yang dituntut dibentuk melalui pembelajaran berkelanjutan: dimulai dengan meningkatkan kompetensi pengetahuan tentang jenis, kaidah, dan konteks suatu teks, dilanjutkan dengan kompetensi keterampilan menyajikan suatu teks tulis dan lisan baik terencana maupun spontan dengan pelafalan dan intonasi yang tepat, dan bermuara pada pembentukan sikap kesantunan berbahasa. Sesuai dengan pendekatan yang digunakan dalam Kurikulum 2013, peserta didik diajak menjadi berani untuk mencari sumber belajar lain yang tersedia dan terbentang luas di sekitarnya

\subsection{Metode Pembelajaran}

Metode menurut Djamaluddin dan Abdullah Aly dalam Kapita Selekta Pendidikan Islam, berasal dari katameta berarti melalui, dan hodos jalan. Jadi metode adalah jalan yang harus dilalui untuk mencapai suatu tujuan. Sedangkan menurut Depag RI dalam buku Metodologi Pendidikan Agama Islam Metode berarti cara kerja yang bersistem untuk memudahkan pelaksanaan suatu kegiatan guna mencapai tujuan yang ditentukan. Menurut WJS. Poerwadarminta dalam Kamus Besar Bahasa Indonesia, Metode adalah cara yang telah teratur dan terpikir baik-baik untuk mencapai suatu maksud. Berdasarkan definisi di atas, penulis dapat mengambil kesimpulan bahwmetode merupakan jalan atau cara yang ditempuh seseorang untuk mencapai tujuan yang diharapkan.

Adapun yang dimaksud pembelajaran Menurut Gagne, Briggs, dan Wagner dalam Udin S.Winataputra adalah serangkaian kegiatan yang dirancang untuk memungkinkan terjadinya proses belajar pada siswa. Sedangkan menurut UU Nomor 20 tahun 2003 tentang Sisdiknas, pembelajaran adalah proses interaksi peserta didik dengan pendidik dan sumber belajar pada suatu lingkungan belajar. Jadi pembelajaran merupakan proses interaksi siswa dengan pendidik dan sumber belajar pada suatu lingkungan belajar. Pembelajaran merupakan bantuan yang diberikan pendidik agar dapat terjadi proses pemerolehan ilmu dan pengetahuan.

Berdasarkan uraian di atas dapat disimpulkan bahwa yang dimaksud metode pembelajaran adalah cara atau jalan yang ditempuh oleh guru untuk menyampaikan materi pembelajaran sehingga tujuan pembelajaran dapat dicapai.

Metode pembelajaran bermacam- macam jenisnya, setiap jenis metode pembelajaran mempunyai kelemahan dan kelebihan masingmasing, penelitian ini dilakukan tidak hanya menggunakan satu macam metode saja tetapi juga menggunaan beberapa metode yang sampai saat ini masih banyak digunakan dalam proses belajar mengajar.

Menurut Nana Sudjana, terdapat bermacam-macam metode dalam pembelajaran, yaitu metode ceramah, metode tanya jawab, metode diskusi, metode resitasi, metode kerja kelompok, metode demonstrasi dan eksperimen, metode sosiodrama (role-playing), metode problem solving, metode system regu (team teaching), metode latihan (drill), metode karyawisata (field-trip), metode survai masyarakat, dan metode simulasi.

\subsection{Pendekatan Proses}

Berbicara dipandang sebagai keterampilan berbahasa yang sangat penting yang harus dikuasai oleh siswa (Hyland, 2007).Dengan keterampilan berbicara yang baik, seseorang dapat menyebarluaskan pemikiran, pandangan, pendapat, gagasan atau perasannya tentang berbagai hal secara produktif, menarik, dan mudah dipahami. Akan tetapi, keterampilan berbicara merupakan keterampilan berbahasa yang paling sulit dikuasai karena berbicara 
adalah proses kognitif yang sangat rumit (Sibarani, 2007).

Aktivitas berbicara tidak dapat dilepaskan dari budaya baca-tulis (Barton, Hamilton, \& Ivanic, 2000).Budaya baca-tulis (literasi) merupakan kebalikan dari budaya dengarucap (orasi) (Alwasilah, 2005).Orang yang berpendidikan biasa disebut literat karena mampu melakukan keduanya.

Kenyataan menunjukkan bahwa budaya baca-tulis masyarakat Indonesia masih kurang memuaskan (Putra, 2008).Kemampuan membaca dan menulis anak-anak Indonesia berada pada peringkat paling bawah apabila dibandingkan dengan anak-anak Asia (Supriyoko, 2004). Penelitian yang dilakukan IEA Study of Reading Literacy (Elly, 1992) dan Progress in International Reading Literacy Study (PIRLS) (Baer, Baldi, Ayotte, \& Green, 2007) menyimpulkan bahwa kemampuan membaca anak-anak sekolah dasar di Indonesia masih sangat rendah.

Rendahnya budaya baca-tulis disebabkan oleh lemahnya sistem pembelajaran berbicara di sekolah (Anshori, 2003).Kenyataan menunjukkan pembelajaran berbicara kurang mendapatkan perhatian yang sewajarnya (Slamet, 2007).Pembelajaran berbicara sebagai salah satu aspek dalam pembelajaran bahasa kurang ditangani dengan sungguh-sungguh.

Siswa dan guru biasanya lebih menekankan kegiatan pembelajaran terhadap penguasaan materi yang mengarah pada keberhasilan siswa dalam ujian akhir nasional. Padahal, belajar membaca merupakan seperangkat proses yang kompleks dan sulit sehingga memerlukan kerangka metodologi pembelajaran yang jelas pada semua tahapan pembelajaran (Knapp \& Watkins, 2005).

Salah satu upaya untuk meningkatkan kualitas pembelajaran adalah dengan melakukan inovasi model pembelajaran melalui penerapan pendekatan proses genre. Pendekatan ini merupakan perpaduan antara pendekatan proses dan pendekatan genre (Nordin \& Mohammad, 2006; Lee,
Goh, Chan, \& Yang, 2007).

Untuk melakukan inovasi model pembelajaran melalui penerapan pendekatan proses genre itu, harus dikembangkan perangkat pembelajarannya. Perangkat pembelajaran itu mencakup silabus, rencana pelaksanaan pembelajaran, materi ajar, instrumen evaluasi, dan panduan pembelajaran.Perangkat pembelajaran ini perlu dikembangkan berdasarkan pertimbangan bahwa (1) guru memang memerlukan perangkat pembelajaran yang inovatif, dan (2) perangkat pembelajaran itu menjadi panduan guru dalam melaksanakan kegiatan pembelajaran.

Berdasarkan pertimbangan itulah, penelitian ini bertujuan untuk menghasilkan model perangkat pembelajaran menulis berdasarkan pendekatan proses genre bagi siswa SMP.

Secara khusus, tujuan penelitian ini adalah: (1) menghasilkan silabus pembelajaran berbicara berdasarkan pendekatan proses genre bagi siswa SMP, (2) menghasilkan rencana pelaksaaan pembelajaran (RPP) berbicara berdasarkan pendekatan proses genre bagi siswa SMP, (3) menghasilkan materi pembelajaran berbicara berdasarkan pendekatan proses genre bagi siswa SMP, (4) menghasilkan instrumen evaluasi pembelajaran berbicara berdasarkan pendekatan proses genre bagi siswa SMP, dan (5) menghasilkan panduan pembelajaran berbicara berdasarkan pendekatan proses genre bagi siswa SMP.

Menurut Badger \& White (2000), pada dasarnya terdapat tiga pendekatan utama dalam pembelajaran berbicara, yakni (1) pendekatan produk, (2) pendekatan proses, dan (3) pendekatan genre. Akan tetapi, karena setiap pendekatan tersebut memiliki keunggulan dan kelemahan masing-masing, ketiganya dianggap saling melengkapi sehingga disarankan adanya pendekatan baru, yang disebut pendekatan proses genre (Badger \& White, 2000; Kim \& Kim, 2005; $\mathrm{Xu}, 2005$; Kaur \& Chun, 2005; Kim, 2007; dasarnya Yan, 2005; Gao, 2007; dan Lee, Goh, Chan, \& Yang, 2007). 
Menurut Badger \& White (2000), dalam pembelajaran berbicara pada harus dipertimbangkan bahwa berbicara meliputi pengetahuan tentang bahasa seperti yang ditekankan dalam pembelajaran berbicara dengan pendekatan produk dan pendekatan genre), pengetahuan tentang konteks tempat tulisan itu digunakan khususnya tentang tujuan (seperti dalam pendekatan genre), dan keterampilan menggunakan bahasa (seperti dalam pendekatan proses), serta peristiwa pengembangan berbicara melalui pemberdayaan potensi siswa (seperti dalam pendekatan proses), dan melalui penyediaaninput sebagai sumber respon siswa (seperti dalam pendekatan produk dan pendekatan genre). Pendekatan pembelajaran berbicara yang memperhatikan berbagai pertimbangan tersebut disebut pendekatan proses genre (Badger \& White, 2000). Menurut Lee, Goh,

\subsection{Prestasi Belajar}

\subsubsection{Pengertian Prestasi Belajar Menurut para Ahli}

Menurut H. Abu Ahmadi menjelaskan pengertian prestasi belajarsebagai berikut: Secara teori bila sesuatu kegiatan dapat memuaskan suatu kebutuhan, maka ada kecenderungan besar untuk mengulanginya. Sumber penguat belajar dapat secara ekstrinsik (nilai, pengakuan, penghargaan) dan dapat secara ekstrinsik ( kegairahan untuk menyelidiki, mengartikan situasi). Disamping itu siswa memerlukan/ dan harus menerima umpan balik secara langsung derajat sukses pelaksanaan tugas (nilai raport/nilai test).

Definisi di atas dapat disimpulkan bahwa pengertian prestasi belajar ialah hasil usaha bekerja atau belajar yang menunjukan ukuran kecakapan yang dicapai dalam bentuk nilai. Sedangkan prestasi belajar hasil usaha belajar yang berupa nilai-nilai sebagai ukuran kecakapan dari usaha belajar yang telah dicapai seseorang, prestasi belajar ditunjukan dengan jumlah nilai raport atau test nilai sumatif.
Ada beberapa cara untuk meningkatkan prestasi salah satunya adalah dengan memperhatikan dan mencermati gaya belajar dan cara belajar yangbaik.

\subsubsection{Faktor yang Mempengaruhi Prestasi Belajar}

a. Faktor faktor Internal

Faktor internal adalah faktor yang berasal dari individu siswa itu sendiri yang meliputi:

1. Faktor Jasmaniah (fisiologis)

Yang termasuk faktor ini antara lain: penglihatan, pendengaran, struktur tubuh dan sebagainya.

2. Faktor Psikologis

Yang termasuk faktor psikologis antara lain:

a. Intelektul(taraf intelegensi, kemampuan belajar,dan cara belajar

b. Non_Intelektual

Motifasi belajar, sikap, perasaan, minat, kondisi psikis dan kondisi akibat keadaan sosiokultur dan faktor kondisi fisik.

b. Faktor-faktor Eksternal

Yang termasuk faktor eksternal antara lain:

1. Faktor pengaturan belajar disekolah (kurikulum, disiplinsekolah,guru, fasilitas belajar, dan pengelompokan siswa ).

2. Faktor sosial disekolah ( sistem sosial, status sosial siswa, dan interaksi guru dan siswa ).

3. Faktor situasional ( keadaan politik ekonomi, keadaan waktu dan tempat atau iklim).

Berdasarkan pendapat di atas dapat disimpulkan bahwa pada dasarnya faktorfaktor yang mempengaruhi prestasi belajar siswa dapat dibedakan menjadi dua golongan, yaitu faktor yang berasal dari dalam diri individu dan faktor yang berasal dari luar diri individu. Kedua faktor ini akan saling mendukung dan saling berinteraksi sehingga membuahkan sebuah hasil belajar.

19 W. S. Winkel, (1983), hal.43.berterima untuk berinteraksi dengan lingkungan sekitar berbentuk descriptive dan 
procedure. Dalam kenyataannya bahwa siswa seringkali mengeluh dan mengatakan sulit bila guru memberi tugas pada siswa untuk berbicara.Bahkan acapkali siswa sudah mengatakan tidak bisa walaupun belum dimulai.

\subsection{Kerangka Berpikir}

Permainan Dragon Snake adalah metode pembelajaran bahasa, khususnya speaking, yang memberi kesempatan kepada siswa untuk mengalami, menghayati, menilai, dan merefleksi sendiri langkah-langkah mempelaari suatu teks, mulai dari perencanaan hingga pengerjaan tugas akhir teks tersebut. Di sini yang menjadi fokus adalah proses speaking dan penguasaan vocabulary. Keterampilan bahasa yang dikembangkan dengan Permainan Dragon Snake ini adalah speaking.

a. Planning. Pada tahap ini guru membimbing siswa untuk membaca topik yang dipelajari.

b. Organising. Pada tahap ini guru meminta siswa belajar dengan Permainan Dragon Snake

c. Acting. Pada tahap ini guru memfasilitasi siswa melaksanakan kegiatan belajar dengan Permainan DragonSnake

d. Controlling. Pada tahap ini guru menilai kegiatan siswa.

e. Reflecting. Pada tahap ini guru bersama siswa merefleksi kegiatan belajar Permainan Dragon Snake

Penggunaan Permainan Dragon Snake sebagai instrument penelitian dengan pertimbangan bahwa apabila siswa belajar sendiri mereka terlihat masih ragu - ragu dan takut salah.

Mereka juga masih malu dan kurang percaya diri.Sehingga diharapkan dengan Permainan Dragon Snake memberi semangat dan membangkitkan motivasi pada siswa bahwa

speaking . Dan karena siswa bisa bekerjasama dengan kelompok maka mereka dapat berbagi ide sehingga masalah dapat dipecahkan melalui komunikasi antar siswa. Dengan demikian Permainan Dragon Snake memotivasi dan mendorong semangat siswa untuk menulis dengan senang.

\subsection{Hipotesis Tindakan}

Berdasarkan rumusan masalah penelitian, tinjauan pustaka, dan kerangka pemikiran, maka dapat diambil hipotesis tindakan sebagai berikut:

a. Diduga penerapan Permainan Dragon Snake dapat meningkatkan kemampuan berbicara siswa kelas VII-J diSMPN 3 Mranggen tahun ajaran 2016 - 2017

b. Diduga dengan Permainan Dragon Snake dapat meningkatkan motivasi berbicara kelas VII-J teks deskripsi mengenai we love what we do diSMPN 3 Mranggen tahun ajaran 2016 - 2017 dalam berbicara

\section{Metode Penelitian}

\subsection{Jenis Penelitian}

Dalam penelitian ini, peneliti terlibat langsung dalam proses penelitian, serta mempersiapkan sarana penelitian dari perencanaan sampai pelaporan untuk pembelajaran Deskriptif mengenai We Love What We Do dalam pelajaran bahasa Inggris kompetensi berbicara dengan menggunakan metode Permainan Dragon Snake sehingga penelitian ini merupakan penelitian tindakan partisipan, karena terdapat keterlibatan peneliti di dalamnya tersebut.

\subsection{Seting dan Karakteristik Subjek Penelitian}

a. Waktu Penelitian

Kegiatan penelitian dilaksanakan di SMP Negeri 3 Mranggen, Jl. Pucanggading Raya, Batursari, Mranggen. Penelitian dilaksanakan selama 3 bulan, yaitu pada semester Genap mulai bulan Maret sampai dengan bulan Mei 2017. Pemberian tindakan dilakukan pada hari Senin dan Sabtu yang merupakan hari/jam pelajaran dimana penulis mengajar

Bahasa Inggris di kelas VII-J, yang menjadi subjek penelitian.

\section{b. Rencana Tindakan}

Waktu penelitian dilakukan secara berturut - turut selama tiga bulan untuk memperoleh hasil penelitian yang sesuai. Penelitian dimulai dari penyusunan proposal , pelaksanaan tindakan penyusunan laporan 
hasil penelitian.Dengan demikian kegiatan penelitian yang dilakukan disesuaikan dengan jadwal yang telah disusun sebelumnya.

\subsection{Prosedur Penelitian}

Penelitian ini dirancang untuk dilaksanakan dalam dua siklus yaitu Siklus I dan Siklus II. Perbedaan kedua siklus terletak pada judul vocabulary yang digunakan yaitu Siklus I menjawab soal dalam bentuk kalimat lepas, sedangkan Siklus II menjawab soal dengan kalimat lebih kompleks. Pemilihan keduanya disesuaikan dengan tujuan yang ingin dicapai pada Kompetensi siswa kelas VII semester genap.

Adapun tahapan perencanaan dan pelaksanaan kedua siklus tersebut pada prinsipnya adalah sama, sebagaimana pendapat Kemmis dan Mc Taggart (1988) bahwa siklus terdiri atas a) perencanaan (Planning), b) tindakan (Acting), c) pengamatan (Observing), dan d) refleksi (Reflecting).

\section{Perencanaan (Planning)}

Peneliti merancang tindakan berdasarkan tujuan penelitian sebagaimana telah dijabarkan di atas. Beberapa instrumen yang disiapkan yaitu rencana pembelajaran (RPP), buku bahan ajar, lembar kerja untuk siswa (kertas folio bergaris), lembar observasi. Vocabulary mengenai jobs dipilih untuk Siklus I dan Siklus II.

\section{Pelaksanaan Tindakan (Acting)}

Kegiatan pokok pada Siklus I:

Kegiatan Pendahuluan, Kegiatan Inti dan Kegiatan Penutup. Kegiatan pendahuluan meliputi salam dan tegur sapa, presensi pemberian motivasi dan apersepsi serta penjelasan tentang tujuan pembelajaran yang hendak dicapai. Kegiatan inti mencakup melihat tayangan gambar dari LCD mengenai gambar contoh - contoh jobs / professions, penjelasan ciri-ciri kebahasaan teks berbentuk descriptive, tata bahasa Simple Present Tense, dan kosakata terkait tema; Siswa dibagi menjadi 4 dan masing - masing kelompok terdiri dari 8 dan 7 anak; penjelasan tentang kegiatan yang akan dilaksanakan yaitu menentukan tugas masing - masing kelompok (Ketua / leader dari dragon, guards / penjaga / pemberi soal / Korektor). Kelompok yang kalah menjadi ular siswa yang tidak maju menyanyikan lagu untuk mengiringi game tersebut Guru melakukan penilaian kerja kelompok; membimbing siswa bila mengalami kesulitan: pengumpulan hasil game dan dievaluasi oleh guru; menjelaskan dan memotivasi untuk berani berbicara dengan Bahasa Inggris Sedangkan Kegiatan penutup meliputi pemberian apresiasi pada semua siswa, pemberian tugas mandiri, dan do'a penutup.

\section{Pengamatan (Observing)}

Selama pelaksanaan tahap Tindakan, dilakukan pengamatan/observasi terhadap aktivitas kegiatan siswa saat beraktivitas dalam kelompok. Pengamatan dilakukan dengan menggunakan instrumen berupa lembar observasi yang telah disiapkan. Komponen dalam lembar observasi mencakup rekaman atas pengamatan proses pembelajaran mulai tahap pendahuluan, kegiatan inti, dan penutup.

\section{Refleksi (Reflecting)}

Isian lembar instrumen pengamatan (lembar observasi) kegiatan pembelajaran dikaji secara teliti. Setelah melihat hasil pengamatan dan hasil siswa ditindaklanjuti untuk perbaikan dan peningkatan kegiatan pembelajaran pada siklus berikutnya. Hasil belajar siswa dalam bentuk lembar kerja dikaji lebih mendalam dalam tahapan ini. Hasil belajar juga disajikan dalam bentuk tabel agar lebih komunikatif. Dalam tabel Indikator Capaian Belajar tersebut mencakup jumlah kelompok yang anggotanya bisa menjawab lebih banyak dari pertanyaan yang disediakan. Hasil observasi/pengamatan terhadap aktivitas proses belajar siswa. Dari kegiatan refleksi terhadap hasil belajar siswa dan hasil observasi, dapat ditentukan langkah lanjut dalam kegiatan pembelajaran berikutnya, agar kegiatan belajar mengajar lebih optimal dan mengantarkan siswa pada pencapaian kompetensi dasarnya.

Empat tahapan di atas tidak hanya 
dilakukan pada Siklus I, tetapi juga dilaksanakan pada Siklus II. Hasil refleksi dari Siklus I menjadi dasar bagi pelaksanaan Siklus II terutama tahapan perencanaan dan tindakan. Pada Siklus II dilakukan tindakan yang lebih baik, agar kekurangan-kekurangan yang terjadi di Siklus I tidak terulang lagi di Siklus II.

\subsection{Data dan Cara Pengumpulannya Sumber Data}

Dalam penelitian ini, sumber data yang digunakan merupakan data primer dan data sekunder. Data primer adalah data yang diperoleh langsung dari sumbernya, dalam hal ini adalah siswa kelas VII - J SMP Negeri 3 Mranggen Semester Genap Tahun Pelajaran 2016/2017, sedangkan data sekunder adalah data yang diperoleh tidak secara langsung dari sumbernya, dalam hal ini adalah data perkembangan siswa.

\subsection{Instrumen Pengumpulan Data}

Dalam penelitian ini, instrumen penelitian yang dipakai adalah sebagai berikut:

Lembar Observasi

Observasi dilakukan oleh peneliti terhadap proses belajar mengajar di kelas yang dilakukan oleh guru kelas bersama dengan teman sejawat untuk mengetahui cara mengajar guru di kelas dan kondisi siswa pada saat menerima pelajaran dari guru kelas.

Evaluasi Hasil Belajar (Tes)

Setelah siswa mengikuti pembelajaran, siswa diminta mengerjakan posttest/evaluasi yang berupa tes formatif. Pelaksanaan evaluasi dimaksudkan untuk mengetahui ada dan tidaknya peningkatan nilai yang dicapai oleh siswa sebagai indikator peningkatan hasil belajar siswa.

\subsection{Indikator Kinerja}

Penelitian tindakan kelas ini berhasil apabila hasil belajar siswa meningkat dengan asumsi pencapaian ketuntasan klasikal sebesar $85 \%$ dan nilai rata-rata kelas lebih besar dari KKM.

\subsection{Analisis Data}

Analisis Data Kuantitatif
Data penelitian ini terdiri atas data yang berbentuk angka-angka dan data yang berbentuk deskripsi kata-kata. Data yang berbentuk angka yang diperoleh dari hasil tes (sesuai petunjuk LKS), diolah untuk mendapatkan nilai rata-rata (mean).

\subsection{Analisis Data Kualitatif}

Untuk data kualitatif, analisis data dilakukan dengan cara menata secara sistematis hasil pengamatan dan tindakan di kelas sehingga diperoleh sebuah deskripsi data yang utuh dan runtut. Analisis data kualitatif terdiri atas (1) analisis selama pengumpulan data dan (2) analisis setelah masa pengumpulan data.

Menganalisis hasil pekerjaan siswa yang dihasilkan pada setiap siklus. Melakukan pemilahan data sesuai dengan strategi pembelajaran yang diterapkan. Sementara itu, langkah-langkah analisis data setelah pengumpulan data selesai adalah sebagai berikut: Mempelajari kembali keseluruhan analisis yang dilakukan pada saat pengumpulan data. Melakukan penambahan, pengembangan, dan perbaikan-perbaikan terhadap analisis yang telah dilakukan sebelumnya. Menyusun simpulan sementara.

\section{Hasil Penelitian Dan Pembahasan}

Hasil penelitian yang meliputi deskripsi kondisi awal, deskripsi hasil siklus I, deskripsi hasil siklus II, pembahasan hasil penelitian, dan hasil tindakan yang kami paparkan sebagai berikut:

\subsection{Hasil Penelitian}

Keberhasilan pembelajaran dapat dilihat dari seberapa jauh siswa mencapai kompetensi yang diharapkan . Keberhasilan siswa sendiri tidak terlepas dari peran guru dalam proses pembelajaran.

Pada kondisi sebelum penelitian tindakan kelas ini, pembelajaran bahasa Inggris di SMPN 3 Mranggen yang diterapkan oleh guru biasanya hanya ceramah, tanya jawab dan penugasan.

Pada kegiatan pembelajaran ini siswa masih belum mendapat hasil yang maksimal. 
Keberhasilan siswa pada kondisi awalini masih jauh dari harapan batas minimum 70, sehingga perlu dilaksanakan tindak lanjut pada siklus - siklus berikutnya.

\section{a. Deskripsi Pra Siklus}

Kondisi awal atau pra siklus merupakan gambaran awal kemampuan anak sebelum mereka mendapatkan pelajaran dengan Permainan Dragon Snake.

Hasil tes yang diberikan pada kondisi awal adalah sebagai berikut:

Tingkat penguasaan siswa terhadap materi berbicara deskripsi tentang We Love What We Do masih kurang. Rata - rata nilai siswa 67,5,dibawah KKM 70.

\section{b. Deskripsi Siklus 1}

Keberhasilan belajar siswa pada siklus 1 adalah diperoleh dengan rata- rata nilai 78.4. dari KKM 70. Nilai Sikap Siswa Kelas VII- J SMPN 3 Mranggen pada siklus 1

Aktifitas belajar siswa pada siklus 1 mencapai $77,4 \%$ atau ada 11 siswa dari 31 siswa yang masih belum antusias dan aktif.

\section{c. Deskripsi Siklus 2}

Nilai Siswa Kelas VII- J SMPN 3 Mranggen pada siklus 2.Keberhasilan belajar siswa pada siklus 2 diperoleh dengan rata- rata nilai 86,1 dari KKM 70 .

Nilai Sikap Siswa Kelas VII-J SMPN 3 Mranggen pada siklus 2.Aktifitas belajar siswa pada siklus 2 meningkat menjadi 100 $\%$ atau 31 siswa / seluruh siswa antusias dan aktif dalam mengikuti pembelajaran.

\subsection{Pembahasan}

Pembahasan Antar siklus

Kemampuan berbicara siswa akan lebih terlihat manakala mereka dapat bekerja sama dalm kelompok . Didalam kelompok siswa akan banyak menyampaikan ide tanpa merasa takut kemudian mereka menjawab / menebak tentang professions/ jobs materi We Love what We do.

Penelitian ini melalui dua siklus. Antara siklus I dan siklus II mempunyai hubungan erat sekali dalam meningkatkan kompetensi belajar siswa. Pada siklus 1 diperoleh ratarata nilai 67,7 dan pada siklus 2 diperoleh dengan rata- rata nilai 81,1 .
Kegiatan pembelajaran juga meningkatkan motivasi belajar siswa terlihat dari jumlah anak yang antusias dan aktif belajar meningkat dari $77,4 \%$ siswa pada siklus 1 menjadi $100 \%$ siswa pada siklus 2 .

Dengan demikian dapat disimpulkan bahwa Dragon Snake Play dapat meningkatkan kemampuan berbicara siswa kelas VII_J Semester 2 Permainan Dragon Snake diSMPN 3 Mranggen tahun ajaran 2016 2017 dalam teks deskripsi mengenai We Love What We Do dan dapat meningkatkan motivasi berbicara kelas VII -J diSMPN 3 Mranggen tahun ajaran 2016 - 2017 dalam berbicara materi We Love What We Do ditandai dengan naiknya nilai rata - rata dan meningkatnya motivasi belajar siswa.

\section{Penutup}

\subsection{Kesimpulan}

Penerapan Dragon Snake Play dalam pembelajaran dapat meningkatkan kemampuan siswa dalam berbicara untuk materi deskripsi We Love What We Do dalam bahasa Inggris untuk menebak jobs/ professions. Aktifitas belajar siswa dengan penerapan Dragon Snake Play dalam pembelajaran berbicara teks deskripsi mengenai We Love What We Do dapat meningkatkan motivasi berbicara kelas VII - J diSMPN 3 Mranggen tahun ajaran 2016 - 2017 dalam menulis teks deskripsi mengenai We Love What We Do ditandai dengan naiknya nilai rata - rata dan meningkatnya motivasi belajar siswa.

\subsection{Saran}

Ada beberapa saran yang berkaitan dengan pembelajaran yang menerapkan Dragon Snake Play, yaitu:

a. Kegiatan ini memerlukan perencanaan yang matang karena persiapan yang diperlukan cukup banyak

b. Kegiatan ini juga membutuhkan waktu yang agak lama karena bertahap dari persiapan pelaksanaan, evaluasi dan umpan balik kegiatan. Materi yang diberikan harus disesuaikan dengan kemampuan siswa Sekolah Menengah Pertama. 
c. Pembagian kelompok dalam mengerjakan tugas harus seimbang dalam kemampuan antara kelompok yang satu dengan yang lain sehingga perlu kecermatan dari kita.

d. Penilaian harus terus dilakukan selama pembelajaran.

e. Pemanfaatan waktu harus diperhatikan

\section{DAFTAR PUSTAKA}

Arikunto, Suharsimi. 2006. Dasar-dasar Evaluasi Pendidikan. Jakarta: Bumi Aksara

Cooper J. David .2000.Literacy : Helping Children Contruct Meaning.New York:Houghton Mifflin Company

Dimyati dan Mudjiono, 2006.Belajar dan Pembelajaran.Jakarta : Direktorat Pendidikan Dasar dan Menengah .

Hughey, Jane B. Dkk. 1983. Teaching ESL Composition: Principles and

Technique. Cambridge: Newburry House Publisher, Inc

Imam, Syafi,1.1996. Terampil Berbahasa Indonesia (Petunjuk Guru Bahasa

Indinesia Sekolah Menengah Umum kelas 1) Jakarta: Balai Pustaka

Keraf, Goris.2007. Komposisi: Sebuah Pengantar Kemahiran Berbahasa.

Semarang Nusa Indah

Latief, H.M. Penelitian Tindakan Kelas Pembelajaran Bahasa Inggris, Jurnal

Pendidikan, Jilid 10, Nomor 2, Juni 2003

Nana Sudjana. 1989. Penilaian hasil Proses Belajar Mengajar. Bandung: PT Remaja Rosda Karya

Nurkancana, Wayan dan P.P.N. Sunartana, 1990. Evaluasi Hasil Belajar. Srabaya:

Slameto,2003. Belajar dan Faktor-faktor yang mempengaruhinya: Jakarta: Rineka Cipta.

Sudijono Anas. 1995. Pengantar Evaluasi Pendidikan. Jakarta: PT. Grafindo

Persada

Sukardi,2005.

Metodelogi Pendidikan : Kompetensi dan Praktinya. Jakarta: PTBumi
Pengetahuan Tentang Kompetensi Guru denganEfektivitas Manajemen kelas, Jurnal Ilmu Pendidikan ParameterUniversitas NegeriJakarta, No. 15 tahun XIX, September, 2002 Suryosubroto, B.2002. Belajar Mengajar diSekolah. Jakarta: RinekaCipta

Wiriaatmadja,Rochiati.2007 Metode PenelitianTindakan Kelas: Untuk

meningkatkan Kinerja Guru dan Dosen. Bandung: PT Remaja 